Reprod. Nutr. Dévelop., 1981, 21 (3), 441-454.

\title{
An immunocytological study of the adult crab-eating macaque (Macaca fascicularis) pituitary and its cytological differentiation during fetal life
}

\author{
par E. DANCHIN $\left({ }^{(}\right)$, D. C. DANG $\left({ }^{(}\right)\left({ }^{2}\right)$, M. P. DUBOIS $\left({ }^{3}\right)$ \\ (1) Laboratoire d'Anatomie, Université René-Descartes \\ UER Biomédicale, 45, rue des Saints-Pères, 75270 Paris Cedex 06. \\ ( $\left.{ }^{2}\right)$ Laboratoire de Physiologie de la Reproduction, Université Paris VI, \\ ef INRA, 78350 jouy en josas, France. \\ ( $\left.{ }^{3}\right)$ Station de Physiologie de la Reproduction, INRA, \\ Nouzilly 37380 Monnaie, France.
}

\begin{abstract}
Summary. The pituitaries of adult and fetal crab-eating macaques (Macaca fascicularis) have been studied by immunofluorescence using 15 antibodies against most of the known hormones in the adenohypophysis. The antibodies used were first checked on adult pituitaries for their cross-specificity with macaque pituitary hormones. We found five types of endocrine cells reacting positively, according to the biochemical relation of the molecules evidenced with one or more of the antibodies used. The sequential appearance of the various hormones in the cells of the anterior and intermediate lobes was then determined. The first hormones evidenced at day 45 of pregnancy were ACTH, $\beta-\mathrm{MSH}, \beta$ - and $\gamma$-LPH and $\alpha$ - and $\beta$-endorphins. $\alpha-\mathrm{MSH}$ appeared at day 48 and STH at day 51 . The glycoprotein hormones, LH, FSH and TSH, appeared at day 57 but the thyrotropes and gonadotropes did not attain their adult characteristics (staining intensity, morphology, density and distribution in the pituitary) until days 71 and 93 , respectively. Prolactin was only found beginning at day 93 of pregnancy.

The different specificity tests applied to the pituitary of the macaque, as well as to that of other vertebrates, show that the antibodies used have good specificity. A comparison of the dates at which the fetal pituitary gonadotropes appear in the macaque and the results of a developmental study of the external genital organs in that species indicated that the pituitary gonadotropic function is only established after somatic sex differentiation, which would thus probably occur independently.
\end{abstract}

\section{Introduction.}

Due to the fact that it affects many vital functions in mammals, the adenohypophysis was early considered as a composite organ. Cytochemical studies of that gland have shown several cell types, each responsible for the secretion of a parficular hormone (Herlant, 1960, 1964 ; Girod, 1963). With the advent of immunocytology, our knowledge of pifuitary cytology has broadened. This technique, widely used in vertebrates (see review in Girod, 1977), especially in monkeys (Girod and Dubois, 1974, 1976a, b, c, 1977) and humans (Mendelsohn et al., 1979 ; Phifer et al., 1970), has indicated that the adenohypophysis of mammals is composed of five different types of 
endocrine cells : gonadotropes, thyrotropes, somatotropes, lactotropes and corticotropes.

In this paper, immunocytological techniques have been used to study pituitary ontogenesis; the specificity and sensitivity of this method permitted us to treat the problem of cytological differentiation of the fetal pituitary at early developmental stages and thus the putative role of the pituitary during fetal differentiation. Since there is no precise data on this subject in non-human primates, we used the crabeating macaque (Macaca fascicularis) as a model.

\section{Material and methods.}

We studied 17 fetal pituitaries, obtained by cesarian (Dang, 1977) and fixed by intracardiac flushing then immerged in Bouin-Hollande with or without acetic acid, without or with sublimate (final concentration of sublimate : 0.5 p. 100) for 3 to 8 days. After washing and dehydration, the pituitaries were embedded in paraffin.

Fetal age was counted from the first day that the female was put with the male for 24 or $48 \mathrm{hrs}$, i.e. between days 13 and 15 of the menstrual cycle, a time when the animal may ovulate. The sex was determined according to methods which have been described previously (Dang, 1978).

The age, sex and fixative used are shown in table 1. The sexual development of macaque males having been well studied, we preferred to use male fetuses when possible in order to be able to compare our results on the pituitary with the processes of sex differentiation in the macaque male fetus.

TABLE 1

Age, sex and fixatives of fetuses

\begin{tabular}{|c|c|c|c|c|c|c|c|c|c|}
\hline Age (days) & 38 & 39 & 45 & 48 & 51 & 53 & 57 & 64 & 71 \\
\hline $\operatorname{Sex} \ldots \ldots \ldots \ldots$ & $\hat{0}$ & $\hat{0}$ & $\hat{0}$ & $q$ & $\sigma$ & 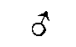 & o & 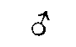 & $\hat{\sigma}$ \\
\hline Fixative ....... & $\mathrm{BHS}$ & BHS & $\mathrm{BH}$ & BHS & $\mathrm{BH}$ & BHS & $\mathrm{BHS}$ & $\mathrm{BHS}$ & BHS \\
\hline Age (days) $\ldots$. & 84 & 93 & 102 & 117 & 121 & 130 & 141 & 150 & \multirow{3}{*}{$\begin{array}{l}\text { day } 165 \\
\text { mean age at par- } \\
\text { turition. Extremes: } \\
150 \text { and } 175 \text { days }\end{array}$} \\
\hline$\overline{\operatorname{Sex} \ldots \ldots \ldots \ldots}$ & 우 & 우 & 0 & 우 & q & $\delta$ & $\hat{0}$ & q & \\
\hline Fixative & BHS & BHS & $\mathrm{BHS}$ & $\mathrm{BHS}$ & BHS & $\mathrm{BHS}$ & BHS & $\overline{\mathrm{BHS}}$ & \\
\hline
\end{tabular}

BHS : Sublimate Bouin-Hollande without acetic acid.

BH : Bouin-Hollande with acetic acid.

Serial sections $5-\mu$ thick, mounted in 0.5 p. 100 gelatinous water, were treated by indirect immunofluorescence using 15 immunsera ( $3 \mathrm{hrs}$ at $1 / 200$ ) prepared in the rabbit against total gonadostimulins or their $\beta$-subunits (LH, FSH, $\beta$-LH, FSH absorbed with hCG *), the $\beta$-subunit of thyrostimulin $(\beta-T S H)$, prolactin (PRL), somatotropin (STH), corticotropin ((1-24) and (17-39) ACTH fragments), melanotropins ( $\alpha$ and $\beta$ MSH), lipotropins ( $\beta$ and $\gamma-L P H)$ and $\alpha$ and $\beta$-endorphins (see table 2 for origin of antigens).

\footnotetext{
* oFSH absorbed with hCG : $20000 \mathrm{IU}$ hCG/ml pure sheep FSH antibodies.
} 
TABLE 2

Origin of immunogens used in preparing the ontisera

\begin{tabular}{ll}
\hline \multicolumn{1}{c}{ Immunogen } & \multicolumn{1}{c}{ Origin and reference } \\
\hline LH & \\
FSH & ovine (CNRS, M $\left.)_{2}\right)$ \\
$\beta-$ LH & ovine (CNRS, M2) \\
hCG & porcine (Dr Courte, INRA) \\
$\beta-T S H$ & human Clin Byla \\
PRL & bovine (antiserum, Dr Pierce, Los Angeles) \\
STH & bovine (NIH, PB ${ }_{2}$ ) \\
ACTH (17-39) & human (KABI, Stockholm) \\
ACTH (1-24) & porcine synthesis (Ciba Geigy, Bale) \\
$\alpha-M S H$ & synthesis (Ciba Geigy, Bale) \\
$\beta-M S H$ & bovine synthesis (Ciba Geigy, Bale) \\
$\beta-$-LPH & synthesis (Ciba Geigy, Bale) \\
$\gamma$-LPH & porcine (Dr Graaf, Budapest) \\
$\alpha$-endorphin & porcine (Dr Graaf, Budapest) \\
$\beta$-endorphin & (Dr Guillemin, San Diego) \\
& (Dr Guillemin, San Diego) \\
\hline
\end{tabular}

We used fluorescein-conjugated sheep antibodies against rabbit $\gamma$-globulins (Institut Pasteur, Paris).

Two adult female pituitaries, one from a gravid female at day 83 of pregnancy and the other from a female ovariectomized 33 days previously, were flushed with 10 p. 100 formol then immerged after dissection in Bouin-Hollande sublimate without acetic acid (BHS) to check the affinities of the different cell types for the various antibodies.

The specificity of the staining obtained with the various immunsera on these adult pituitaries was monitored in several ways : (i) by omitting the first antibody, (ii) by replacing it with the non-immune serum of normal rabbit or (iii) by previous incubation of the antibody in the presence of homologous or heterologous immunogens. The specificity of the reactions obtained with these various antibodies has been studied in previous works (see review by Ferran ef al., in press, of antibody against polypeptides).

\section{Results.}

All the antibodies gave positive labelling on adult pituitaries.

The different specificity tests carried out on the same pituitaries demonstrated that antibody specificity in this study was satisfactory (table 3 ). The absence of inhibition by (1-24) ACTH of anti- $\alpha$ and $\beta-M S H$ and of anti- $\beta$ and $\gamma$-LHP demonstrated that their major determinant did not concern the heptapeptide (4-10) ACTH common to all these peptides.

By comparing the cells evidenced by different antibodies on adjacent sections (Plates I, II), we distinguished five distinct cell types in the anterior lobe : gonadotropes (positive in the presence of anti- $\beta-\mathrm{LH}$, anti-LH, anti-FSH and anti-FSH absorbed with hCG), thyrotropes (strongly positive to anti- $\beta-T S H$ and weakly positive to anti-LH and anti-FSH), lactotropes (positive to anti-PRL), somatotropes (positive to anti-STH) 
TABLE 3

Immunofluorescence observed in the presence of immune-serum incubated previously with different homologous and heferologous immunogens

\begin{tabular}{|c|c|c|c|c|c|c|}
\hline \multirow{2}{*}{ Antibody } & \multicolumn{6}{|c|}{ Immunogens } \\
\hline & No immunogen & $\beta L H_{o v}$ & $\mathrm{LH}_{\mathrm{DV}}$ & $\mathrm{TSH}_{\mathrm{ov}}$ & $\mathrm{STH}_{\mathbf{h}}$ & $\mathrm{PRL}_{\text {ov }}$ \\
\hline$\beta-L_{\text {por }} \quad \ldots \ldots$ & +1 & - & - & + & & \\
\hline $\mathrm{LH}_{\mathrm{ov}} \ldots \ldots \ldots$ & $+1,11$ & +- & - & +- & & \\
\hline $\mathrm{FSH}_{\mathrm{ov}} \ldots \ldots \ldots$ & $+1,11$ & + & +- & +- & & \\
\hline $\mathrm{FSH}_{\mathrm{ov}}+\mathrm{hCG} \ldots$ & +1 & + & +- & +- & & \\
\hline$\beta$-TSH $H_{\text {bov }} \ldots \ldots$ & +11 & + & + & - & & \\
\hline $\mathrm{STH}_{\mathrm{h}} \ldots \ldots \ldots$ & $+\mathrm{III}$ & & & & - & + \\
\hline $\mathrm{PRL}_{\mathrm{OV}} \ldots \ldots \ldots$ & + IV & & & & + & - \\
\hline
\end{tabular}

Antibody

Immunogens

No immunogen $\quad(1-24) \mathrm{ACTH} \quad \alpha-\mathrm{MSH} \quad \beta-\mathrm{MSH} \quad \alpha$-endorphin $\quad(17-39) \quad$ ACTH

\begin{tabular}{|c|c|c|c|c|c|c|}
\hline (17-34) ACTH ... & $+\mathrm{V}, \mathrm{VI}$ & + & & & & - \\
\hline (1-24) ACTH .... & $+V, V I$ & - & $t$ & + & & \\
\hline$\beta-M S H \ldots \ldots$. & $+V, V I$ & + & + & - & & \\
\hline$\alpha-M S H \quad \ldots \ldots \ldots$ & $+\mathrm{VI}$ & + & - & + & & \\
\hline$\beta$-LPH $\ldots \ldots \ldots$ & $+\mathrm{V}, \mathrm{VI}$ & + & & + & + & \\
\hline$\gamma-\mathrm{LPH} \ldots \ldots \ldots$ & $+V I$ & + & + & + & & \\
\hline$\alpha$-endorphin $\ldots$. & $+\mathrm{V}, \mathrm{VI}$ & + & & & - & \\
\hline$\beta$-endorphin $\ldots$ & $+\mathrm{V}, \mathrm{VI}$ & + & & & & \\
\hline
\end{tabular}

positive response, - negative response, + - lower response than control.

I : gonadotropes, II : thyrotropes, III : somatotropes, IV : lactotropes, V : corticotropes of adenohypophysis, VI : corticotropes of intermediate lobe.

\section{PLATE I}

Macaque pituitary.

1. Pituitary of 57-day fetus stained by anti- $\alpha-M S H$. Only intermediate lobe cells are positive. $\times 360$.

2. Adjacent section stained by anti- $\beta$-MSH shows the same intermediate lobe cells with some anterior lobe cells. $\times 360$. LA : anterior lobe. LI : intermediate lobe.

3. Ovariectomized female pituitary : cells stained by anti- $\beta-L P H . \times 440$.

4. Adjacent section stained by anti-(17-39) ACTH. The same cells (arrows) are stained by both antibodies. × 440.

5. Pregnant female pituitary : cells stained by anti- $\beta-T S H . \times 440$.

6. Adjacent section stained by the same antibody incubated beforehand with TSH. Labelling has totally disappeared. Dashes outline the vessels common to both sections. $\times 440$. 

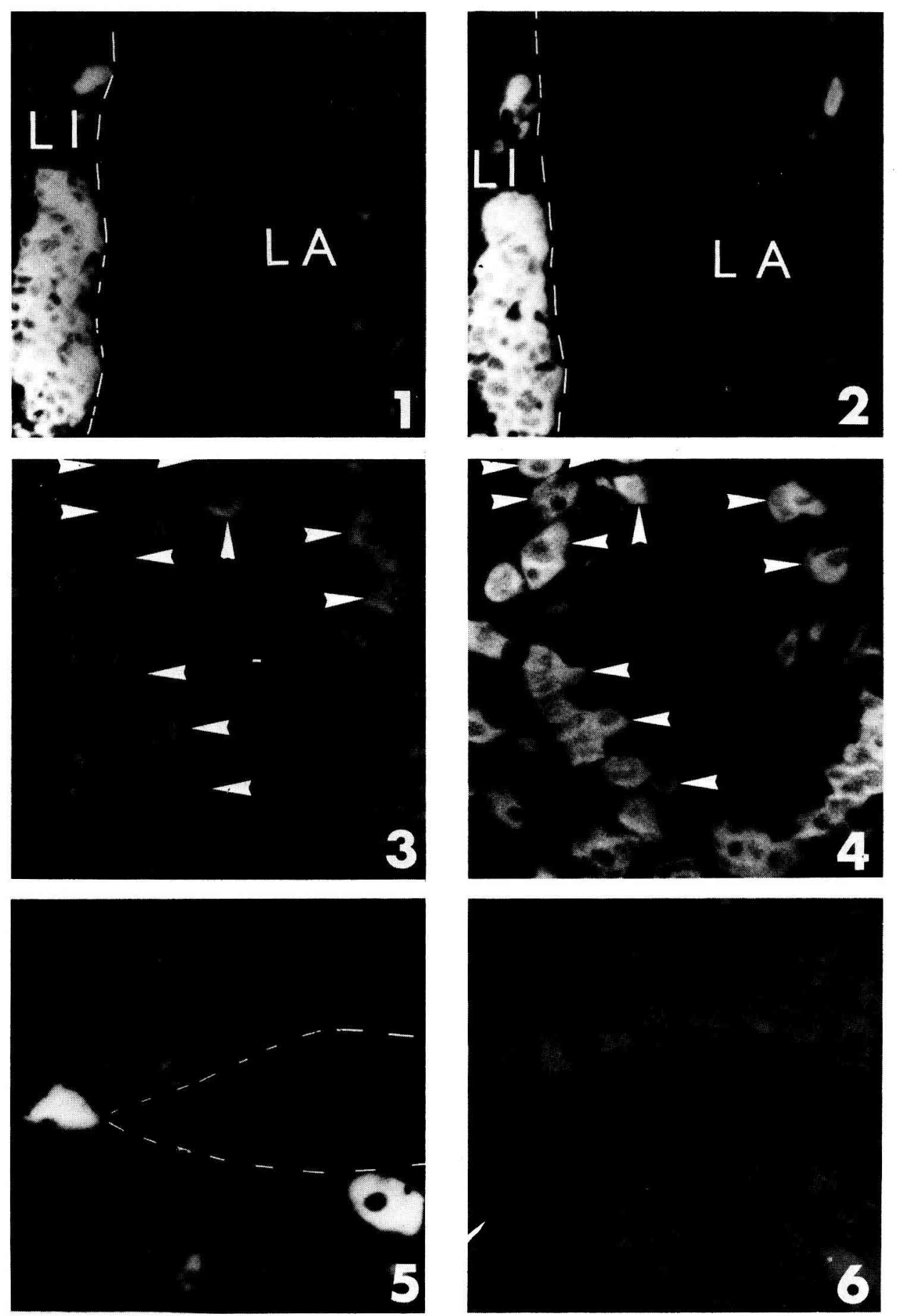
and corticotropes which were always positive to anti-(1-24) and (17-39) ACTH as well as to anti- $\beta-M S H$ and anti- $\beta-L P H$; some of these cells were also positive to anti- $\alpha$ and/or $\beta$-endorphins.

The intermediate lobe cells and some in the anterior lobe, close to the intermediate lobe, were corticotropes, but they reacted very strongly with anti- $\alpha-\mathrm{MSH}$ and anti- $\gamma$-LPH (Plate 1, 1 and 2).

The general morphology and distribution of the cell types differed ; for example, the thyrotropes and gonadotropes were easily distinguishable. The former, rather large with abundant cytoplasm, were densely localized in the zone where the portal vessels emerge. The gonadotropes were much smaller; their cytoplasm was reduced to a thin crown around the nucleus and they were more evenly distributed in the whole distal pituitary.

. In the fetuses (table 4 ; Plate III), we obtained no positive labelling at days 38 and 39 of pregnancy. At day 45 , the antibodies against (1-24) and (17-39) ACTH, $\beta-M S H$, $\beta$-LPH and $\alpha$ and $\beta$-endorphins gave the first positive responses in the anterior and the intermediate lobes; the latter lobe was also labelled weakly by the anti- $\gamma$-LPH but not by the anti- $\alpha-M S H$, which only labelled weakly the intermediate lobe cells at day 48

\section{TABLE 4}

Summory of important dates in the cytological differentiation of the adenohypophysis in the crab-eating macaque

$\begin{array}{ll}\text { Days } 38 \text { and } 39 & \text { No positive labelling observed } \\ \text { Day } 45 & \text { First corticotropes (polypeptidic hormones except } \alpha-M S H) . \\ \text { Day } 48 & \text { First weak anti- } \alpha-M S H \text { labelling (optimal reaction at day } 51 \text { ). } \\ \text { Day } 51 & \text { First somatotropes. } \\ \text { Day } 57 & \text { First gonadotropes and thyrotropes ( } \alpha \text { and } \beta \text {-subunits). } \\ \text { Day } 71 & \begin{array}{l}\text { Thyrotropes seem to have attained an appearance and number similar to those } \\ \text { observed in adult cells. } \\ \text { Gonadotropes attain a number and appearance similar to those observed in adult } \\ \text { cells. Morphologically distinct from the thyrotropes. } \\ \text { Fay } 93\end{array} \\ \text { Farturition. } & \text { Pactotropes. }\end{array}$

\section{PLATE II}

Macaque pifuitary.

1. Ovariectomized female pituitary : cells stained by anti- $\beta-\mathrm{LH} . \times 440$.

2. Adjacent section. The same cells are stained by anti-FSH absorbed with hCG (arrows). $\times 440$.

3. 117-day fetus : cells stained by anti- $\beta-T S H . \times 440$.

4. Adjacent section. The cells stained by anti-FSH absorbed with hCG are different from those in the preceding section. $\times 440$.

5. Ovariectomized female pituitary : cells stained by anti- $\beta-T S H . \times 440$.

6. Adjacent section stained by anti- $\beta-L H$. Cells are not the same. The dashes outline the anatomical structures common to both sections. $\times 440$. 

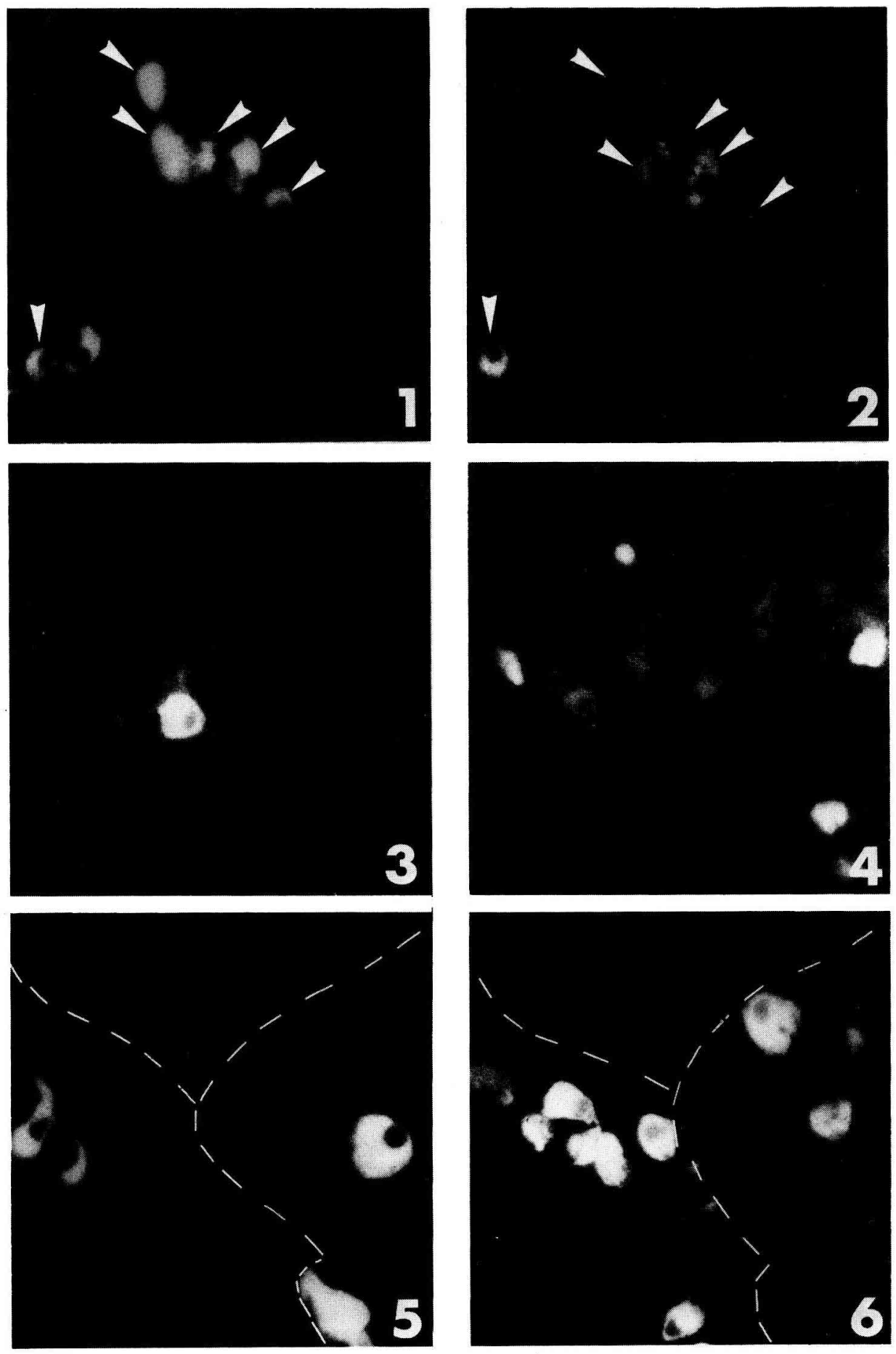
and reached a maximal response at day 51 . In the adenohypophysis, all these labels were immediately maximal in a large number of cells and remained maximal throughout pregnancy. At day 51, many somatotropes reacted strongly with anti-STH, and further labellings were constant up to parturition.

At days 57, some cells were well labelled by anti-LH, anti- $\beta-L H$ and anti- $\beta-T S H$ but only weakly by anti-FSH and anti-FSH absorbed with hCG. The number of gonadotropes and thyrotropes was still low at day 64 and a large number did not appear until day 71 when the thyrotropes seemed to have reached a normal developmental stage, while the gonadotropes only began to show characteristics similar to adult cells (general staining intensity, morphology, distribution and density in the pituitary) at about 93 days, and particularly at 102 days.

Lactotropes could only be identified beginning at day 93 ; they were found in small numbers and showed little reactivity up to the end of fetal life (Plate III, 8).

\section{Discussion.}

Our study of the adult crab-eating macaque (Macaca fascicularis) pituitary showed the five conventional endocrine cell types in that gland (Girod, 1977 ; Racadot, 1977).

While it is not very difficult to evidence thyrotropes, somatotropes or lactotropes, the gonadotropes and corticotropes still present problems.

In agreement with other authors (Nakane, 1970 ; Phifer et al., 1973 ; Herbert, 1976 ; El Etreby et Fath El Bab, 1977 ; Dacheux, 1978, 1979 ; Tougard et al., 1980), our study of adjacent sections, evidenced by anti- $\beta-\mathrm{LH}$ and anti-FSH absorbed with hCG, suggests that the cytoplasm of most gonadotropes contains both the hormones. The validity of such an affirmation is supported by the specificity of the antibodies involved. However, if, in the present study, anti- $\beta-\mathrm{LH}$ never stained thyrotropes (morphologically different from gonadotropes), we sometimes noticed that anti-FSH absorbed with hCG weakly labelled thyrotropes. Thus, the anti-FSH absorbed with hCG would still contain a contaminating agent against the $\alpha$-subunit of glycoprotein hormones; this would partly explain the diminution, but not the annulation, of the reactions observed during $\mathrm{LH}$ and $\mathrm{TSH}$ saturation of that antibody (table 3 ).

\section{PLATE III}

Fetal macaque piluitary.

1. 45-day fetus : first cells stained by anti-(17-39) ACTH. $\times 360$.

2. 51-day fetus: cells stained by anti-STH. $\times 360$.

3. 57-day fetus : cells stained by anti- $\beta-L H . \times 640$.

4. 57-day felus : cells stained by anti-LH. $\times 640$.

5. 51-day fetus : cells stained by anti- $\alpha$-endorphin.$\times 360$.

6. 71-day fetus : cells stained by anti-FSH absorbed with hCG. $\times 640$.

7. 93-day felus : cells stained by anti- $\beta-T S H . \times 360$.

8. 93-day fetus : cells stained by anti-PRL. $\times 360$. 


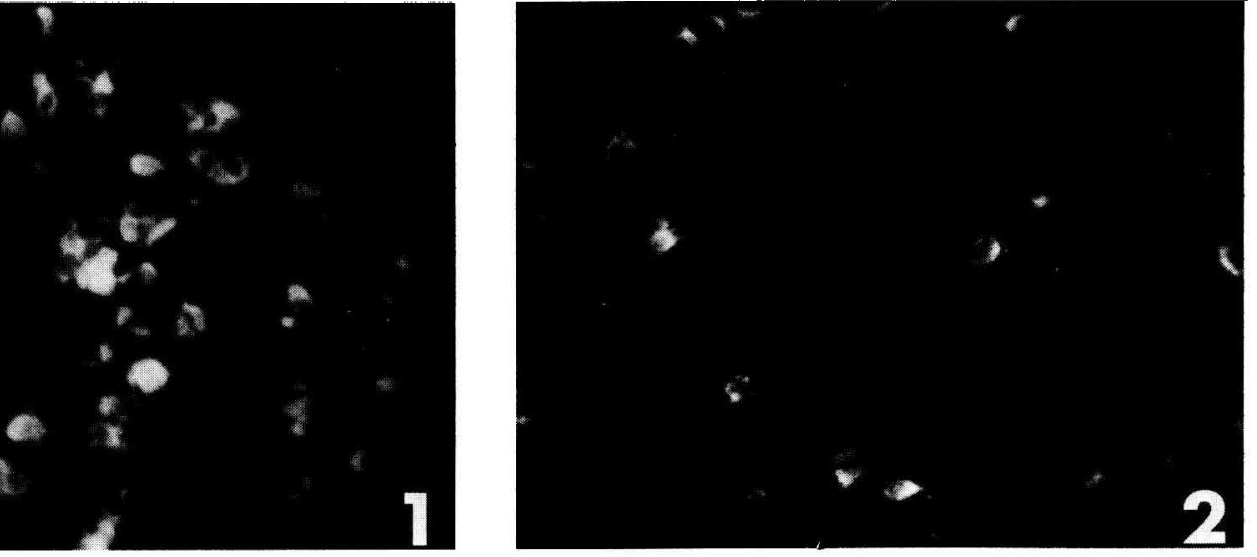


The corticotropes present the same problem in a more acule way, i.e. numerous peptides were evidenced in these cells. As so many authors, we found that all the corticotropes in the adenohypophysis react to anti-(17-39) and (1-24) ACTH, anti- $\beta-M S H$ and anti- $\beta$-LPH (Dessy and Herlant, 1974 ; Dubois and Graf, 1973 ; Tramu and Dubois, 1977 ; Girod et Dubois, 1977 ; Pelletier et al., 1977 ; Moon et al., 1972), while only some react to anti- $\alpha$-and/or $\beta$-endorphins (Bloom ef al., 1977 ; Mendelsohn ef al., 1979). Besides these six antibodies, the intermediate lobe cell also react with anti- $\alpha-M S H$ and anti- $\gamma$-LPH.

Moriarty et al. (1975), experimenting in various conditions, reported a marked difference in the reactivity of corticotropes, depending in whether they were situated in the anterior or the intermediate lobe. From the point of view of their immunological content and function, the so-called « corticotropes » seem to group several slightly different cell types.

All these histological and cytological characteristics have been found in the 17 fetuses studied. Our results agree with the order of appearance of the different cell types (table 4) found by authors studying fetal development in different mammalian species (rat : Watanabe and Daikoku, 1979 ; Dupouy and Dubois, 1975 ; Setalo and Nakane, 1976 ; sheep : Stokes and Boda, 1968 ; cattle : Dubois, 1971a, b ; pig : Dubois, 1977 ; humans : Baker and Jaffe, 1975 ; Bugnon ef al., 1976a, b ; Celio, 1979).

A study by Jost ef al. $(1966 a, b)$ on further adrenal development in the rat fetus after in ufero decapitation led those authors to suggest the early differentiation of pituitary corticotropes. We observed these cells as early as day 45 in the anterior and intermediate lobes with all the antibodies used, except anti- $\alpha-M S H$. The late appearance of this hormone has already been reported in humans (Bugnon ef al., 1976a; Dupouy and Dubois, 1975).

The appearance of these various peptides at the same date and in the same cells agrees with the hypothesis of a common precursor for this group of hormones (Mains et al., 1977).

At day 51, we observed many differentiated somatotropes. This early date agrees well with the results of the above-mentioned authors. Only the rat seems to be an exception (Setalo and Nakane, 1976 ; Watanabe and Daikoku, 1979).

When the first gonadotropes and thyrotropes appeared at day 57, we did not observe any dissociation between the $\alpha$ and $\beta$-subunits of those hormones. This phenomenon seems to be particular to humans (Bugnon ef al., 1976b ; Dubois ef al., 1975). On the other hand, we noticed that the thyrotropes only attained their adult number and morphology in 71-day fetuses. The number of gonadotropes increased from day 71 but they did not begin to resemble those of the adult until about day 93, reaching good resemblance at day 102. From that day, the two cell types could be distinguished solely by their morphological differences.

Thus, since the pituitary gonadotropes appear clearly later than sex gonad differentiation at aboul day 40 (Dang et Fouquet, 1979) and external genital organ formation at days 57 and 58 (Dang, 1978), it seems that these differentiate without the intervention of the pituitary gonadotropic function.

Moreover, from day 66 of pregnancy, the Leydig cells are in full involution (Fouquet ef al., 1978) ; this is expressed by a drop in umbilical blood circulating testosterone at the same dates (Dang and Meusy-Dessolle, 1979). It thus seems that at this 
period, the gonadotropic hormones synthesized and present in the anterior pituitary lobe are not truly excreted, the lack of gonadotropic stimulation probably causing Leydig cell involution. Only an endocrine balance, taking into account the rate of gonadotropic hormones circulating in the plasma, would provide exact data on this subject.

In all studied species, gonadal differentiation, and genital tract differentiation too, occurs before the appearance of pituitary cells showing an immune reaction with antibodies against gonadotropic hormones (rat : Jost, 1972 ; Dupouy and Dubois, 1975 ; Chatelain ef al., 1976 ; Setalo and Nakane, 1976 ; Watanabe and Daikoku, 1979 ; pig : Patten, 1948 ; Danchin and Dubois (in preparation) ; man : Raynaud, 1969 ; Baker and Jaffe, 1975 ; Bugnon et al., 1974, 1976a, b). The gonad and the genital tract thus seem to differentiale independently of the pituitary.

Finally, we have evidenced lactotropes only from day 93, their labelling remaining weak up to day 117. Most authors agree that this cell type differentiates late, and is generally the last to be immunostainable.

\section{Conclusion.}

Using the primate, Macaca fascicularis, we studied the patterns of functional differentiation of the various endocrine cell types in the pituitary during fetal development.

Does this pituitary cell differentiation occur independently as it seems to with rat corticotropes (Begeot et al., 1979) or is it under the influence of hypothalamic releasing factors, as indicated by the earlier appearance of LH-RH in man (Bugnon et al., 1977)? This problem remains to be solved.

Reçu en août 1980.

Accepté en décembre 1980.

Acknowledgements. - This work was carried out under DGRST contract No 8070357. The authors thank Dr. Ch. Thibault for his helpful advice and Dr. A. Delmas for his encouragement.

Résumé. Une étude de l'hypophyse adulte et fotale de Macaque Crabier (Macaca fascicularis) a été faite par immunofluorescence à l'aide de 15 anticorps dirigés contre la plupart des hormones connues comme étant présentes dans le lobe antérieur de l'hypophyse. Sur les hypophyses d'adultes, après avoir vérifié que les anticorps utilisés croisaient d'une manlère spécifique ayec les hormones hypophysaires de Macaque, nous avons pu constater la présence de 5 types de cellules endocrines chacune réagissant positivement, selon la parenté biochimique des molécules ainsi mises en évidence, avec un ou plusieurs des anticorps utilisés. Nous avons ensuite pu établir une séquence d'apparition des différentes hormones dans les cellules du lobe antérieur et intermédiaire de l'hypophyse. Les premières hormones mises en évidence sont, à 45 jours de gestation, l'ACTH, la $\beta-M S H$, la $\beta$ et $\gamma-L H P$, l' $\alpha$ ef la $\beta$-endorphine. A 48 jours apparaît l' $\alpha$-MSH. A 51 jours la STH fait son apparition. A 57 jours apparaissent les hormones glycoprotéiques : $\mathrm{LH}, \mathrm{FSH}$ et $\mathrm{TSH}$, mais l'aspect de ces cellules n'est proche de celui des cellules de l'hypophyse d'adulte (intensité des marquages, morphologie, densité et répartition de ces cellules dans l'hypophyse) que vers 71 jours pour les cellules thyréotropes et vers 93 jours pour les cellules gonadotropes. La prolactine n'a été mise en évidence qu'à partir du 93 jour de la gestation. 
Les différents tests de spécificité pratiqués, aussi bien sur les hypophyses de cette espèce, que sur des hypophyses d'autres espèces de vertébrés, montrent une bonne spécificité des anticorps utilisés. La comparaison de la date d'apparition des gonadotropines hypophysaires fœtales avec les résultats de l'étude du développement des organes génitaux externes de cette même espèce permet de penser que la fonction gonadotrope hypophysaire ne se met en place effectivement que bien après la différenciation sexuelle somatique, celle-ci devant donc se dérouler d'une manière autonome.

\section{References}

BAKER B. L., JAFFE R. B., 1975. The genesis of cell types in the adehohypophysis of the human fetus as observed with immuno-cyto-chemistry. Am. J. Anat., 143, 137-162.

BEGEOT M., DUBOIS M. P., DUBOIS P. M., 1979. Influence de l'hypothalamus sur la differenciation des cellules présentant une immunoréactivité de type $A C T H, \beta L P H$ ( $\beta$-lipotropine), $\alpha$ et $\beta$ endorphines dans les ébauches antéhypophysaires de fotus de rat en culture organotypique. $J$. Physiol. Paris, 75, 27-31.

BLOOM F., BATTENBERG E., ROSSIER J., LING N., LEPPALUOTO J., VARGO T., GUILLEMIN R., 1977. Endorphins are located in the intermediate and anterior lobes of the pituitary gland, not in the neurohypophysis. Life Sci., 20, 43-48.

BUGNON C., LENYS D., BLOCH B., FELLMANN D., 1974. Etude cyto-immunologique des phénomènes de différenciation cellulaire précoce dans l'adéhohypophyse fœale humaine. C. R. Soc. Biol., 168, 460-465.

BUGNON C., LENYS D., BLOCH B., FELLMANN D., 1976a. Exploration cyto-immunologique sur coupes semi-fines des phénomènes de différenciation précoce de diverses populations cellulaires dans l'adénohypophyse fotale humaine. C. R. Soc. Biol., 170, 975-982.

BUGNON C., BLOCH B., FELLMANN D., 1976b. Etudes cyto-immunologiques des cellules gonadotropes du fotus humain. Bull. Ass. Anat., 60, 259-268.

BUGNON C., BLOCH B., FELLMANN D., 1977. Immunological study of the ontogenesis of the gonadotropic hypothalamo-pituitary axis in the human fetus. J. Ster. Bioch., 8, 565-575.

CELIO M. R., 1979. Distribution of $\beta$-endorphin immunoreactive cells in human fetal and adult pituitaries and in pituitary adenomas. J. Histochem. Cytochem., 27, 1215.

CHATELAIN A., DUBOIS M. P., DUPOUY J. P., 1976. Hypothalamus and cytodifferentiation of the fetal pituitary gland : study in vivo. Cell Tiss. Res., 169, 335-344.

DACHEUX F., 1978. Ultrastructural localization of gonadotrophic hormones in the porcine pituitary using the immunoperoxidase technique. Cell Tiss. Res., 191, 219-232.

DACHEUX F., 1979. Are FSH and LH contained in the same granules? IRCS Med. sci., 7, 280-281.

DANCHIN E., DUBOIS M. P. Etude immunocytologique de la différenciation des cellules endocrines de l'hypophyse foetale de porc et des neurones hypothalamiques à LHRH dans la première moitié de la gestation (en préparation).

DANG D. C., 1977. Resumption of menstruation and fertility after cesarian in Macaca fascicularis Ann. Biol. anim. Bioch. Biophys., 17, 325-329.

DANG D. C., 1978. Sexual differentiation of the external genital organs of the Macaca fascicularis fetus. Ann. Biol. anim. Bioch. Biophys., 18, 681-687.

DANG D. C., FOUQUET J. P., 1979. Differentiation of the fetal gonad of Macaca fascicularis with special reference to the festis. Ann. Biol. anim. Bioch. Biophys., 19, 1197-1209.

DANG D.C., MEUSY-DESSOLLE N., 1979. Testosterone levels in umbilical cord blood, maternal peripheral plasma and amniotic fluid of the crab-eating monkey (Macaca fascicularis). Ann. Biol. anim. Bioch. Biophys., 19, 1307-1316.

DESSY C., HERLANT M., 1974. Localisation comparée des immunosérums antilipotropine, anticorticotropine et antimélanotropine $\beta$ au niveau de l'hypophyse du porc. C. R. Acad. Sci. Paris, sér. $D, 278$, Série $D, 1923-1926$.

DUBOIS M. P., 1971a. Les cellules corticotropes de l'hypophyse des bovins, moutons et porcs. Ann. Biol. anim. Bioch. Biophys., 11, 589-624. 
DUBOIS M. P., 1971b. Mise en évidence par immunofluorescence des cellules somatotropes et des cellules à prolactine dans l'hypophyse fotale des bovins. C. R. Acad. Sci. Poris, sér. D, 27̇2, 433435.

DUBOIS M. P., 1977. Sur les sécrétions hormonales polypeptidiques du complexe mère-fœłus au $30 \mathrm{e}$ jour de la gestation dans l'espèce porcine. Bull. Soc. Zool. Fr., Suppl. 1, 63-70.

DUBOIS M. P., GRAF L., 1973. Demonstration by immunofluorescence of the lipotropic hormone/LPH in bovine, ovine and porcine adenohypophysis. Horm. Mefob. Res., 5, 229-230.

DUBOIS P. M., BEGEOT M., DUBOIS M. P., 1975. Dissociation entre les sous-unités $\alpha$ et $\beta$ de LH dans l'antéhypophyse fœetale humaine. Ann. Endocr., 36, 321-322.

DUPOUY J. P., DUBOIS M. P., 1975. Ontogenesis of the $\alpha M S H, \beta M S H$ and ACTH cells in the fetal hypophysis of the rat. Correlation with the growth of the adrenals and adrenocortical activity. Cell Tiss. Res., 161, 373-384.

EL ETREBY M. F., FATH EL BAB M. R., 1977. Localization of gonadotrophic hormones in the dog pituitary gland. Cell Tiss. Res., 183, 167-175.

FERRAN R., FREMONT P. H., DUBOIS M. P. Immunocytological study on the differentiation of grafted or in vitro-cultured chick and quail adenohypophysis epithelial rudiment : evidence for polypeptidic hormones. Amer. J. Anat. (In press).

FOUQUET J. P., DANG D. C., MEUSY-DESSOLLE N., 1978. Functional differentiation of Leydig cells in the testis of the fetal monkey (Macaca fascicularis). Ann. Biol. anim. Bioch. Biophys., 18, 12051221.

GIROD C., 1963. Application de la méthode d'Herlant (1960) à l'étude cytologique du lobe glandulaire de l'hypophyse chez le Singe (Macaca sylvianus L.) mise en évidence de 6 types cellulaires chromophiles. C. R. Soc. Biol. Paris, 157, 297-300.

GIROD C., 1976. Histochemistry of the adenohypophysis. In GRAUMANN W., NEUMANN K., Handbuck der Histochemie. Vol. III, 325 pp. G. Fischer Ed., Stuttgart.

GIROD C., 1977. Apport de l'immunohistochimie à l'étude cytologique de l'adénohypophyse. Bull. Ass. Anat., 62, 417-603.

GIROD C., DUBOIS M. P., 1974. Observations sur le lobe intermédiaire et sur le lobe infundibulotubéral de l'adénohypophyse chez le singe (Macacus irus F. Cuv). Bull. Ass. Anat. 58, 557-561.

GIROD C., DUBOIS M. P., 1976a. Identification en immunofluorescence de différentes catégories de cellules adénohypophysaires (cellules somatotropes, à prolactine, corticotropes, mélanotropes, gonadotropes et thyréotropes) chez le Spermophile (Citellus variegatus) et le Graphiure (Graphiurus murinus). C. R. Soc. Biol., 170, 1236-1238.

GIROD C., DUBOIS M. P., 1976b. Mise en évidence, par immunofluorescence, des cellules somatotropes et des cellules à prolactine chez les singes Erythrocebus patas, Cercopithecus aethiops et Papio hamadryas. C. R. Soc. Biol., 170, 1215-1220.

GIROD C., DUBOIS M. P., 1976c. Immunofluorescent identification of somatotropic and prolactin cells in the anterior lobe of the hypophysis (pars distalis) of the monkey (Macacus irus). Cell Tiss. Res., 172, 145-148.

GIROD C., DUBOIS M. P., 1977. Mise en évidence par immunofluorescence des cellules corticotropes ef des cellules mélanotropes de l'adénohypophyse chez les singes Erythrocebus pafas, Cercopithecus aethiops et Papio hamadryas. C. R. Soc. Biol., 171, 367-372.

HERBERT D. C., 1976. Immunocytochemical evidence that luteinizing hormone (LH) and follicle stimulating hormone (FSH) are present in the same cell type in the rhesus monkey pituitary gland. Endocrinology, 98, 1554-1557.

HERLANT M., 1960. Ełude critique de deux techniques nouvelles destinées à mettre en évidence les différentes catégories cellulaires présentes dans la glande pituitaire. Bull. Micr. appl., 10, 37-44.

HERLANT M., 1964. The cells of the adenohypophysis and their functional significance. Int. Rev. Cytol., $17,299-382$.

JOST A., 1972. Données préliminaires sur les stades initiaux de la différenciation du testicule chez le rat. Arch. Anat. micr. Morph. exp., 61, 415-438.

JOST A., COHEN A., 19660. Signification de l'atrophie des surrénales foetales du rat provoquée par l'hypophysectomie (décapitation). Dévelop. Biol., 14, 154-168.

JOST A., DUPOUY J. P., MONCHAMP A., 1966b. Fonction corticotrope de l'hypophyse et hypothalamus chez le foetus de rat. C. R. Acod. Sci. Paris, sér. D, 262, 147-150. 
MAINS R. E., EIPPER B. A., LING N., 1977. Common precursor to corticotropins and endorphins. Proc. nat. Acad. Sci. USA, 74, 3014-3018.

MENDELSOHN G., D'AGOSTINO R., EGGLESTON J. C., BAYLIN S. B., 1979. Distribution of $\beta-$ endorphin immunoreactivity in normal human pituitary. J. clin. Invest., 63, 1297-1301.

MOON H. D., LI C. H., JENNING B. M., 1972. Immunohistochemical and histochemical studyies of pituitary ß-lipotrops. Anat. Rec., 175, 529-538.

MORIARTY G. C., HALMI N. S., MORIARTY C. M., 1975. The effect of stress on the cytology and immunocytochemistry of pars intermedia cells in the rat pituitary. Endocrinology, 96, 14261436.

NAKANE P. K., 1970. Classification of anterior pituitary cell types with immunoenzyme histochemistry. J. Histochem. Cytochem., 18, 9-20.

PATTEN B. M., 1948. Embryology of the pig. P. Blakiston's Son \& Co. Philadelphia and Toronto, $3^{\mathrm{e}} \mathrm{Ed}$.

PELLETIER G., LECLERC R., LABRIE F., COTE J., CHRETIEN M., LIS M., 1977. Immunohistochemical localization of $\beta$-lipotropic hormone in pituitary gland. Endocrinology, 100, 770-776.

PHIFER R. F., SPICER S. S., ORTH D. N., 1970. Specific demonstration of the human hypophyseal cells which produce adreno-corticotropic hormone. J. clin. Endocr., 31, 347-361.

PHIFER R. F., MIDGLEY A. R., SPICER S. S., 1973. Immunohistologic and histologic evidence that follicle-stimulating hormone and luteinizing hormone are present in the same cell type in the human pars distalis. J. clin. Endocr., 36, 125-141.

RACADOT J., 1977. Origine cellulaire des hormones hypophysaires. In R. SCHOLLER, Exploration de l'unifé hypothalamo-hypophysaire. Journ. Endocr. clin. Paris-Fresne, Nov. 1977. Edition Sepe Fondation de Recherche en Hormonologie.

RAYNAUD A., 1969. Les organes génitaux des mammifères. In P. P. GRASSÉ, Traité de Zoologie, Vol. 16, fasc. VI, 149-636, Masson Cie, Paris.

SETALO G., NAKANE P. K., 1976. Functional differentiation of the foetal anterior pituitary cells in rat. Endocr. exp., 10, 155-166.

STOKES H., BODA J. M., 1968. Immunofluorescent localization of groth hormone and prolactin in the adenohypophysis of foetal sheep. Endocrinology, 83, 1362-1366.

TOUGARD C., PICART R., TIXIER-VIDAL A., 1980. Immunocytochemical localization of glycoprotein hormones in the rat anterior pituitary. A light and electron microscope study using antisera against rat $\beta$-subunits : a comparison between preembeding and postembedding methods. J. Histochem. Cytochem., 28, 101-114.

TRAMU G., DUBOIS M. P., 1977. Comparative cellular localization of corticotropin and melanotropin in lerot adenohypophysis (Eliomys quercinus). An immunohistochemical study. Cell Tiss. Res., 183, 457-469.

WATANABE Y. G., DAIKOKU S., 1979. An immunohistochemical study on the cytogenesis of adenohypophysial cells in fetal rats. Develop. Biol., 68, 557-567. 